\title{
Can workplace inducements influence labour turnover?
}

\author{
A. M. Ogaboh Agba ${ }^{a, *}$, Pius U. Angioha ${ }^{a}$, Ntiense G. Akpabio ${ }^{a}$, Abayomi Akintola $^{\mathrm{a}}$, \& \\ Gbadebo S. Maruf ${ }^{b}$ \\ ${ }^{a}$ Department of Sociology, University of Calabar, Nigeria \\ ${ }^{b}$ School of Business Management, Universiti Utara Malaysia, Sintok, Kedah, Malaysia
}

\begin{abstract}
The study examines workplace inducements and labour turnover. Specifically, the study sought to establish the relationship between staff promotion, performance-based bonuses, employee discount, training, and labour turnover in the telecommunications industry in South-South, Nigeria. The study adopted a survey research design. Using a self-report questionnaire. Data was collected from five hundred and seventy-two (572) staff selected in four (4) telecommunications industry in South-South, Nigeria. The obtained data were statistically analysed using simple linear regression. Each hypothesis was tested at 0.05 per cent level of significance. The result obtained from the analysis revealed that staff promotion, performance-based bonuses, employee discount and training significantly affect labour turnover in the telecommunications industry in South-South, Nigeria. The study recommended among others that policy options that encourage improved incentives for employees in telecommunications company.
\end{abstract}

Keywords: Workplace inducement; labour turnover; promotion; performance-based bonuses; employee discount.

\section{Introduction}

In all business entities, employees are a key resource and are responsible for the failure or success of their organization. The success depends on the ability of the organization to attract, retain and appropriately motivate competent employees'. According to Armstrong (2003) the willingness of employees to remain in one organisation, irrespective of its type, depends largely on the organization's ability to provide attract motivational packages, flexible schedule, recognition and other fringe benefits, which commiserated with their input. Globally, organizations are judged based on their ability to retain their best hands and the rate at which their employees leave the organisation. Labour turnover has been an ever ending issue for most organizations, especially in developing nations. It can be voluntary and involuntary and can have a disruptive influence on the functioning of the organization (Abbasi \& Hollman, 2000; Iji, Ojong, \& Angioha, 2018). The cost of voluntary turnover is reflected in the recruitment process, temporary staffing, training of new employee etc (Agba, Ushie, Abam, Agba, Okoro, 2010; Adah, Angioha, Ugwuonwu \& Akomaye,)

Labour turnover affects both the organization and the employees. Turnover's effect on the employee disrupts work processes. On the other hand, the organization suffers from loss of competent skills set and there is disruption in their production process. Organisations also suffer from more cost, as a result of hiring new staffs. Evidence from the work of scholars revealed that increased pay, better fringe benefits and other motivational factors elsewhere are among the major reasons for labour turnover (Govindarajulu, Bonnie \& Daily, 2004; Angioha, Nwagboso, Ironbar \& Ishie, 2018). Labour turnover is a good research concept with existing literature focusing on the cause of work and nonwork characteristics turnover. This study, however, examines the relationship between labour and labour turnover in

\footnotetext{
* Corresponding author.

E-mail address: ogabohagbagroup@yahoo.com (A. M. Ogaboh Agba)
} 
the communications industry in South-South, Nigeria. Most Telecommunications industries overtime, especially in Africa, have failed to appreciate, cherish and motivate their employees leading to the feeling of neglect on the part of workers, which most often results in poor productivity. Mitchell, Holton, and Ice (2001) assert that when workers leave an organization, it costs the organizations money and time to find replacements and to retain them. According to Asmamao (2011), the cost of labour turnover to telecommunication companies includes employment cost, human capital cost, orientation cost, training cost and production cost. When establishments suffer from labour turnover, the organization suffers from loss of specific manpower, low productivity, administrative cost, loss of human capital. Also, retraining of new staff brings its problem for this involves money spent on training and getting the new employees settled into their new environment. besides there is also an indirect cost associated with labour turnover; these includes reduced interaction that is possible between employees hereby resulting in the incubation of employee bonds, this natural reduction in staff moral most times leads to decreased in loyalty, hence leading to noncommitment. When an employee who contributes meaningfully to the achievement of organizational goal leaves a telecommunication company permanently, the organization does not just loose a productive workforce, but also finance. It also disrupts operations and social capital depiction. This study examines the relationship between workplace inducements and labor turnover in telecommunication, industry in South-South Nigeria. Specifically, the study seeks to:

Assess the effect of staff promotion on labour turnover in the telecommunications industry in South-South, Nigeria.

(ii) Examine the relationship between performance-based bonuses and labour turnover in the telecommunications industry in South-South, Nigeria.

(iii) Investigate whether employee discount affects labour turnover in the telecommunications industry in SouthSouth, Nigeria.

(iv) Explore the effect of training on labour turnover in the telecommunications industry in South-South, Nigeria.

\section{Literature Review}

Employee inducements have been used and defined in different ways. The UNDP capacity development resources (2006) defined employee inducement as those external means that are designed and put in place to motivate individuals or organizational behaviour. It refers to those management tools that are used by organizational management to motivate and recognize employees level of performance in support of organizing employees' performance and accomplishment (Hartman, Kurtz \& Moser, 1994; Angioha, Omang, Ishie, \& Iji, 2020). They form the core feature of all organization. Dessler (2004) refer to employee inducements as those motives or reward given to employees whose level of performance has exceeded the expected standard. Banyoko (2006) on his part sees employee inducements as those variable payments made to the employee or group of employee as a result of their output based on the achieved result. They are those motivational packages made to employees to increase their performance (Marochio, 2006). Employee inducements are divided into monetary, non-monetary tangible and nonmonetary intangible incentives (Devoe, Plaffer \& Lee, 2013; Agba, Nkpoyen \& Ushie, 2010). Monetary incentives include those financial reward given to employees that is not limited bonuses, pay increase, commissions etc. nonmonetary tangible incentives include coupons, vouchers for food, vacation, etc. non-monetary intangible incentives include recognition, positive evaluation, feedback praises (Coudly, Clark \& Stolowtch, 2013; Iji, Angioha \& Okpa, 2019; Agba, Mboto, \& Agba, 2013).

Labour turnover is one challenging issue that most organization are concerned about. Enterprises has received considerable attention for employers and management of the organization over the impact of turnover on performance (Dailey \& Kark, 1992; Agba, \& Ushie, 2013). Labour turnover refers to the total number of workers/labour that leaves an organization over some time, usually on a yearly basis, and this is calculated as a percentage of all employee members. It refers to the movement of employees in and out of any business organization. It is the rate at which people leave an organization. Labour turnover can be viewed from two dimensions: internal and external turnover. Internal turnover denotes the act of an employee switching position from one level to another within the same organization. While external turnover refers to the process whereby an employee leaves or changes the 
organization. Factors that may bring about external turnover include better pay, better working conditions, improved training job location.

Scholars have made attempts at putting forward a plethora of reasons for labour turnover (Effiom \& Efi, 2017; Ogin \& Omoyele, 2018; Adewole, 2017). Among this factor include;

- Financial factors: Using the monetary model, Mann and Shay (2004) argued that employees leave their current employment for economic and financial reasons. The model argues that employees rationality leave business organizations as a result of financial reasons. This can be used to explain the majority of labour turnover.

- Roles stressor: the rate of organizational turnover is related to task stressor. This is as a result of employees not been fully aware of their task which leads to role inconsistency. This is attributed to lack of inadequate comprehension of what a job task requires, lack of strategies to achieve the goals of the organization. Role stressors may cause an employee to feel isolated and unsatisfied with their work and this brings about lack of dedication, which will make employee exhibit the drive to exit an organization.

- Ineffective communication: Employment of all organization expect to be updated with information concerning their wellbeing organizations with effective communication system tend to record low labour turnover, employees tend to stay longer in organizations where they pant of decision-making practice. But organizations where employee tend to be isolated and in the long nun try to leave the organization.

- Internal policies: policies played internally is said to lead to a high turnover of the employee. Employees of the organization tends stay in an organization when the atmosphere is inspiring and vice versa. Research has shown that in organizations where there is a high rate of incompetence there tends to be labour turnover.

Mendis (2017) using a self-administered structured questionnaire administered on 97 non-executive employees from a logistic company tried to analyse the relationship between reward system and employee turnover intention. The study focused on five reward system; supervisor support, work-life balance, recognition, remuneration and cash incentives. Results from the analysis of data revealed that reward systems are a significant predictor of labour turnover intention. Ghilam and Ali (2019) examined the influence of monetary and nonmonetary rewards on turnover intention. Data for the study was generated from 100 employees working in public banks in Pakistan. Data were analysed using partial list squares structural equation modelling technique. The investigate showed that monetary rewards and competence growth positively relate to motivation, which negatively relates to turnover intention.

Femando and Ranaweena (2019) using 200 hundred employees employed at the Sri Lanka Tourism Development Authority, assessed the influence of non-financial reward on labour retention. Data were collected using a structured questionnaire. Data were analysed using simple linear regression and Baron and Kenny mediation analysis method. Results revealed a negative relationship between non-financial reward and employee retention. Oyoo, Nwandihi and Musega (2016) examined the relationship between reward system and employee retention. Information was collected 113 samples from a faith organization in Kenya. Descriptive and inferential statistics were used for analysis. Result revealed a significant relationship between the reward system and employee retention Sitati, Were and Waithtu (2016) assessed the correlation between job promotion and employee retention in the Hotel Industry in Kenya. The survey research design was adopted in gathering data from a sample of 137 Kenya using a stratified random sampling technique. A structured questionnaire was the instrument of data collection. Inferential and descriptive statistical was used to analyse the collected from the field. Results showed a positive correlation between promotion and employee retention. Carson, Carson, Grifith and Steel (1994) carried out a meta-analysis of promotion and employee turnover. Data was collected from a review of relevant quantitative studies carried out by other scholars. Result revealed a negative correlation between promotion satisfaction and employee turnover.

Hassam, Razi, Qamar, Jaffar and Suhail (2013) examined the influence of training on employee retention. The survey sample was used to collect information from employees of Telecommunications Company. Results revealed a significant correlation between training and employment retention. Chen (2014) in his conference paper examined the 
effect of training on employee retention. Data for the study was gathered from a review of literature on the topic under study. Results from the review revealed a positive correlation between training and employee retention Jang, Kim and Yoo (2007) examine the effect of online training on job duration. It was revealed that employees that took the training stayed at their job longer.

The study adopted the human relations theory which originated from haw throne experiment of Elton Mayo and his colleague in Chicago's western electronic company. The theory holds that an employee drives for recognition, a sense of belonging is an important factor in determining his morale to work than his stamina. It also holds that nonmonetary compensations such as rewards and other fringe benefits are an important factor in determining the productivity of an employee. The theory thinks that informal groups in an organization influence the working habits of the organization. In applying the theory to this study employee turnover in telecommunication companies will reduce if basic employee inducements such as performance-based bonuses, training promotion are made available to workers.

\section{Methods}

The survey research design adopted in this study. This design is employed because it permits for drawing of inferences. This is opted for because the design has to do with the gathering of facts that is correctly and empirically aimed at explaining prevailing occurrences and events. Survey research design is used to investigate the relationship between employee`s incentives and labour turnover in the telecommunications industry in South-South, Nigeria. The population of this study consists of five hundred and seventy-two (572) staff selected from the telecommunications industry in South-South, Nigeria. The spread of the population revealed that Airtel has a population of two hundred and fifteen (215) staff, MTN, one hundred and forty-four (144) staff, Globacom, one hundred and ten (110) staff, while 9mobile has a population of one hundred and three (103) staff. The study population constitute full time employee and non-full time employee whose name appears in the pay roll of the telecommunications industry in South-South, Nigeria. The researchers believe that this population is reliable enough to provide dependable information on the correlates between employee's incentives and labour turnover in the telecommunications industry in South-South, Nigeria. Five hundred and seventy-two (572) respondents were sampled from the six states that made up the South-South geo political region.

Table 1. Population distribution of telecommunication employee in South-South, Nigeria

\begin{tabular}{|c|c|c|c|c|c|c|c|c|c|c|}
\hline \multirow{2}{*}{$\mathrm{S} / \mathrm{N}$} & \multirow{2}{*}{ State } & \multicolumn{2}{|c|}{ AIRTEL } & \multicolumn{2}{|c|}{ MTN } & \multicolumn{2}{|c|}{ GLO } & \multicolumn{2}{|c|}{ 9MOBILE } & \multirow{2}{*}{ Total } \\
\hline & & FTE & NFTE & FTE & NFTE & FTE & NFTE & FTE & NFTE & \\
\hline 1 & $\begin{array}{l}\text { Akwa } \\
\text { Ibom }\end{array}$ & 9 & 32 & 5 & 15 & 5 & 12 & 4 & 10 & 92 \\
\hline 2 & Bayelsa & 3 & 9 & 3 & 6 & 2 & 5 & 2 & 5 & 35 \\
\hline 3 & $\begin{array}{l}\text { Cross } \\
\text { River }\end{array}$ & 5 & 24 & 5 & 18 & 4 & 12 & 3 & 18 & 89 \\
\hline 4 & Delta & 8 & 30 & 7 & 20 & 6 & 16 & 6 & 14 & 107 \\
\hline 5 & Edo & 6 & 28 & 5 & 18 & 5 & 15 & 4 & 12 & 93 \\
\hline 6 & Rivers & 16 & 45 & 10 & 32 & 8 & 20 & 7 & 18 & 156 \\
\hline & Total & 47 & 168 & 35 & 109 & 30 & 80 & 26 & 77 & 572 \\
\hline
\end{tabular}

Data for this study was generated from the distribution of the structured questionnaire. The questionnaire is categorised into three sections: the first section (A) sourced for the bio-data of the respondents. The second section (B) elicits information on incentives (independent variable) is classified into four-point Likert scale rating, which is used to gather data on the key areas of the research that is employees` incentives. Section C elicits information on labour turnover. The questionnaire was designed in a four point Likert scale format. The third section (C) was designed to measure items from the dependent variable that is labour turnover. Analyses of data were carried out based on the research hypotheses formulated. Frequency tables were used to organize the demographic responses into percentages. Each of the questionnaires is coded and a scoring sheet is provided where all responses were scored. The 
correlated between employees` incentives and labour turnover was established using linear regression. All hypotheses were restated in the null form and tested at 0.05 level of significance.

\section{Result and Discussions}

\subsection{Hypothesis one}

Staff promotion does not significantly affect labour turnover in the telecommunications industry in South-South, Nigeria. Both variables were measured continuously. The analysis was done using simple linear regression analysis at a confidence level of 95 per cent. The result is analysed in table 2 .

Table 2. Regression Model of the contribution of staff promotion to labour turnover in the telecommunications industry in South-South, Nigeria

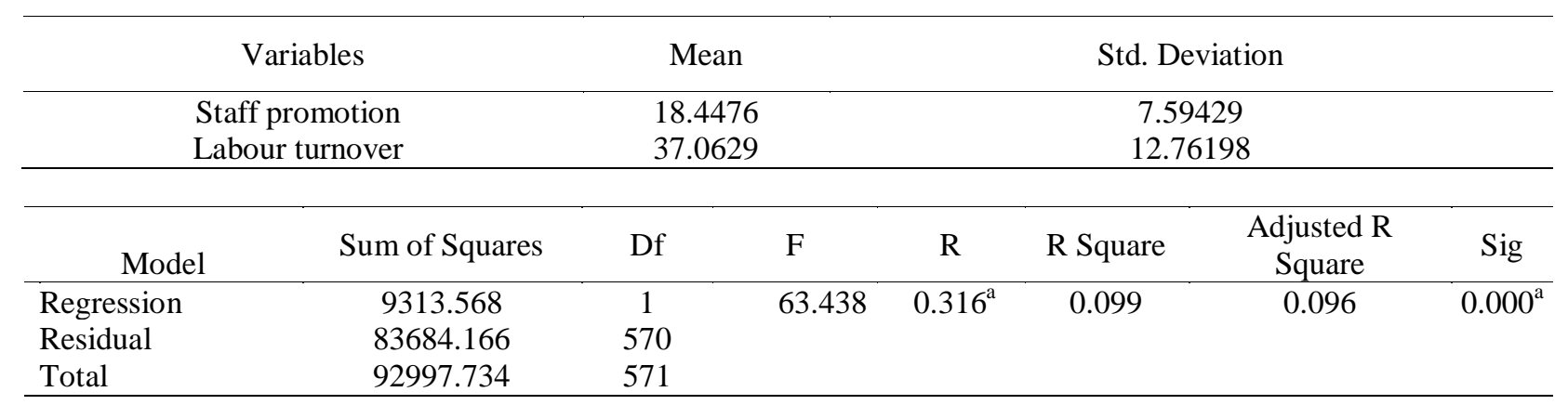

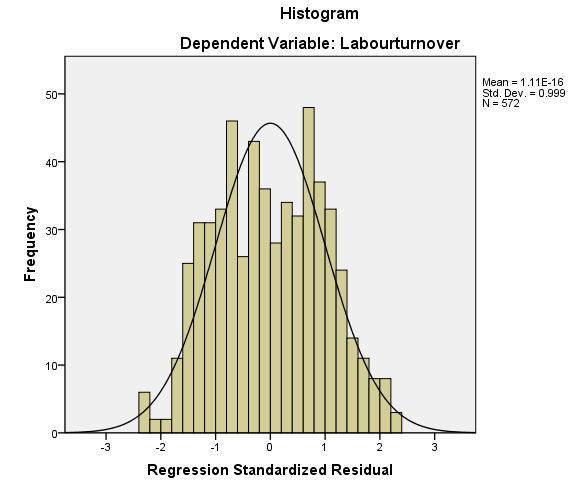

(a)

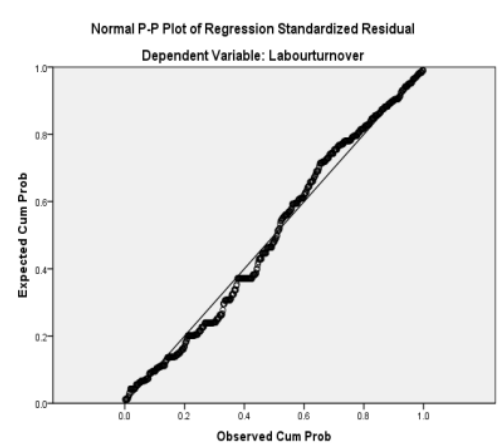

(b)

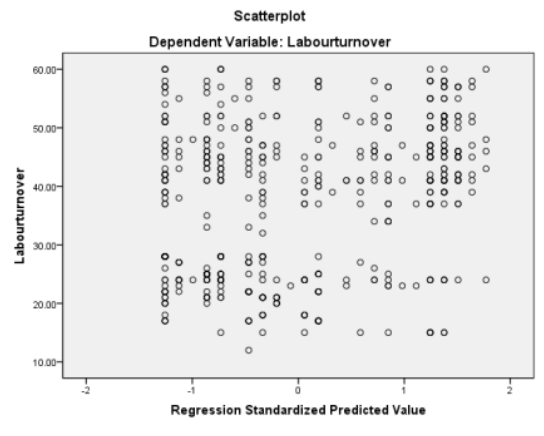

(c)

Fig. 1. Histogram, Normal P-P Plot, and Scatterplot of hypothesis one.

The analysis revealed an $\mathrm{R}$-value of $0.316^{\mathrm{a}}\left(\mathrm{p}=0.000^{\mathrm{a}}<0.05\right)$. With this result the raised hypothesis is rejected, implying a significant contribution of staff promotion to labour turnover. Result also revealed an $\mathrm{R}^{2}$-value of 0.099 suggesting that $99 \%$ variance in labour turnover is accounted for by staff promotion. Also, the ANOVA showed a significant joint linear association (contribution) staff promotion and labour turnover in the telecommunications industry in South-South, Nigeria given by the $F(1,571)=63.438 ; p<0.05$. The adjusted $R^{2}(0.096)$ reveals a little reduction of the unadjusted value (0.099) implying that this model can be generalised for the whole population. With this result, it was decided that staff promotion significantly contributes to labour turnover in the telecommunications industry in South-South, Nigeria. 


\subsection{Hypothesis two}

There is no significant relationship between performance-based bonuses and labour turnover. Both variables were measured continuously. The analysis was done using simple linear regression analysis at a confidence level of 95 per cent. The result is analysed in table 3.

Table 3. Regression Model of the contribution of the relationship between performance-based bonuses and labour turnover in the telecommunications industry

\begin{tabular}{|c|c|c|c|c|c|c|c|}
\hline \multicolumn{4}{|c|}{ Variables } & \multicolumn{2}{|r|}{ Mean } & \multicolumn{2}{|c|}{ Std. Deviation } \\
\hline \multicolumn{3}{|c|}{ Performance based-bonuses } & & & 14.7657 & \multicolumn{2}{|c|}{3.73805} \\
\hline \multicolumn{3}{|c|}{ Labour turnover } & & & 37.0629 & & 198 \\
\hline Model & Sum of Squares & Df & $\mathrm{F}$ & $\mathrm{R}$ & R Square & $\begin{array}{l}\text { Adjusted R } \\
\text { Square }\end{array}$ & Sig \\
\hline Regression & 5750.301 & 1 & 37.568 & $0.249^{\mathrm{a}}$ & 0.062 & 0.060 & $0.000^{\mathrm{a}}$ \\
\hline Residual & 87247.433 & 570 & & & & & \\
\hline Total & 92997.734 & 571 & & & & & \\
\hline
\end{tabular}

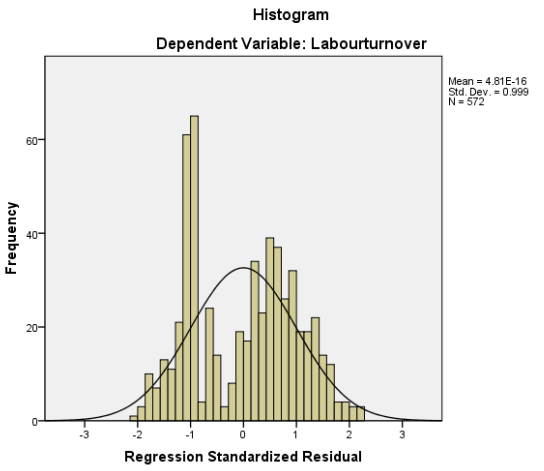

(a)

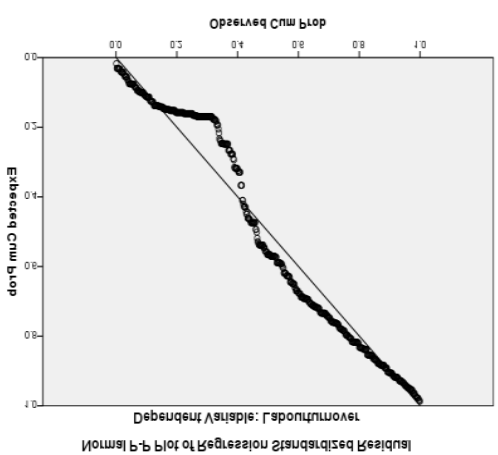

(b)

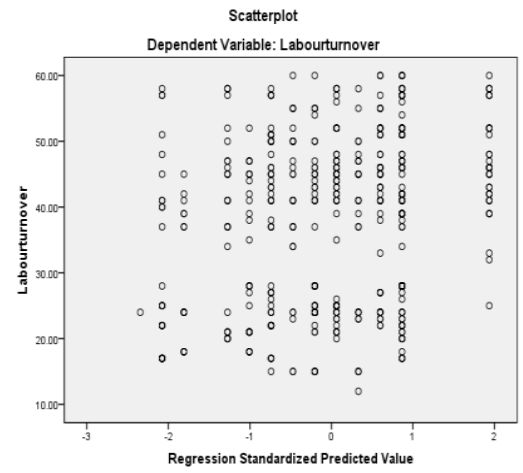

(c)

Fig. 2. Histogram, Normal P-P Plot, and Scatterplot of hypothesis two.

The analysis revealed an $\mathrm{R}$-value of $0.249^{\mathrm{a}}\left(\mathrm{p}=.000^{\mathrm{a}}<0.05\right)$. With this result, the raised hypothesis is rejected, implying a significant contribution of performance-based bonuses to labour turnover. Result also revealed an $\mathrm{R}^{2}-$ value of 0.062 implies that $62 \%$ variance of labour turnover is accounted for by performance-based bonuses. Also, the ANOVA showed a significant joint linear association (contribution) of performance-based bonuses and labour turnover given by the $\mathrm{F}(1,571)=37.568 ; \mathrm{p}<0.05$. The adjusted $\mathrm{R}^{2}(0.060)$ shows some reduction of the unadjusted value (0.062) implying that this model can be generalised for the whole population. With this result, it was decided tha performance-based bonuses significantly contribute to labour turnover in the telecommunications industry in South-South, Nigeria.

\subsection{Hypothesis three}

Employee discount does not significantly affect labour turnover in telecommunications industry in South-South, Nigeria. Both variables were measured continuously Analysis was done using simple linear regression analysis at a confidence level of 95 per cent. The result is analysed in table 4 . 
Table 4. Regression Model of the relationship between employee discount and labour turnover in telecommunications industry

\begin{tabular}{|c|c|c|c|c|c|c|c|}
\hline \multicolumn{2}{|c|}{ Variables } & \multicolumn{2}{|l|}{ Mean } & \multicolumn{3}{|c|}{ Std. Deviation } & \\
\hline \multicolumn{2}{|c|}{ Employee discount } & \multicolumn{2}{|l|}{16.1538} & \multicolumn{3}{|c|}{9.48207} & \\
\hline \multicolumn{2}{|c|}{ Labour turnover } & \multicolumn{2}{|l|}{37.0629} & \multicolumn{3}{|c|}{12.76198} & \\
\hline Model & Sum of Squares & Df & $\mathrm{F}$ & $\mathrm{R}$ & R Square & $\begin{array}{l}\text { Adjusted R } \\
\text { Square }\end{array}$ & Sig \\
\hline Regression & 12196.969 & 1 & 16.042 & $0.234^{\mathrm{a}}$ & 0.066 & 0.064 & $0.000^{\mathrm{a}}$ \\
\hline Residual & 80800.765 & 570 & & & & & \\
\hline Total & 92997.734 & 571 & & & & & \\
\hline
\end{tabular}

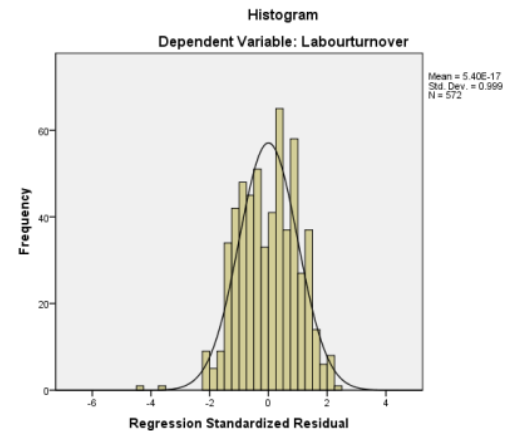

(a)

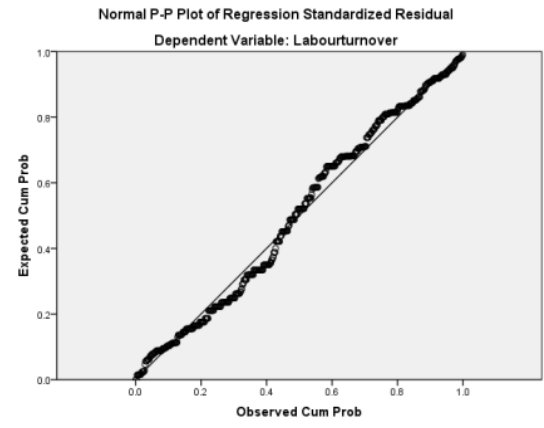

(b)

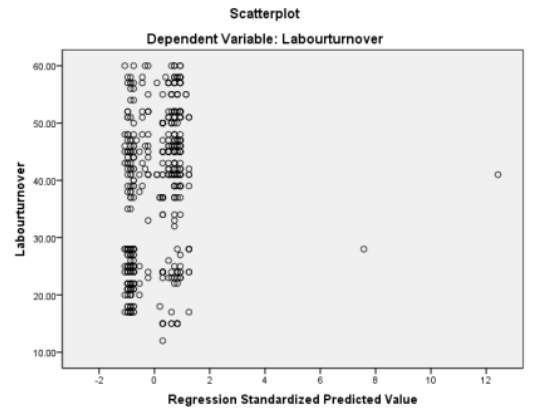

(c)

Fig. 3. Histogram, Normal P-P Plot, and Scatterplot of hypothesis three.

The analysis revealed an R-value of $0.234^{\mathrm{a}}$ at a confidence level of 95 per cent $\left(\mathrm{p}=0.000^{\mathrm{a}}<0.05\right)$, with this result the raised hypothesis is rejected, implying a significant contribution of employee discount to labour turnover Also, the $\mathrm{R}^{2}$ -value of .066 implies that $66 \%$ of the total variance of employee discount is accounted for by employee discount. Also, the ANOVA showed a significant joint linear association (contribution) of the employee discount on labour turnover given by the $\mathrm{F}(1,571)=16.042 ; \mathrm{p}<0.05$. The adjusted $\mathrm{R}^{2}(0.060)$ reveals some reduction of the unadjusted value (0.062) implying that this model can be generalized for the whole population. With this result, it was decided that performance-based bonuses significantly contribute to labour turnover in the telecommunications industry in South-South, Nigeria.

\subsection{Hypothesis four}

Training does not significantly affect labour turnover in the telecommunications industry in South-South, Nigeria. Both variables were measured continuously. The analysis was done using simple linear regression analysis at a confidence level of 95 per cent. 5 .

Table 5. Summary of simple linear regression analysis of the relationship between training and labour turnover in the telecommunications industry

\begin{tabular}{|c|c|c|c|c|c|c|c|}
\hline Variables & \multicolumn{2}{|c|}{ Mean } & \multicolumn{5}{|c|}{ Std. Deviation } \\
\hline Training & \multicolumn{2}{|c|}{14.8304} & \multicolumn{5}{|c|}{8.63510} \\
\hline Labour turnover & \multicolumn{2}{|c|}{37.0629} & \multicolumn{5}{|c|}{12.76198} \\
\hline Model & Sum of Squares & Df & $\mathrm{F}$ & $\mathrm{R}$ & R Square & $\begin{array}{c}\text { Adjusted R } \\
\text { Square }\end{array}$ & Sig \\
\hline Regression & 2851.820 & 1 & 18.032 & $0.175^{\mathrm{a}}$ & 0.031 & 0.029 & $0.000^{\mathrm{a}}$ \\
\hline Residual & 90145.914 & 570 & & & & & \\
\hline Total & 92997.734 & 571 & & & & & \\
\hline
\end{tabular}




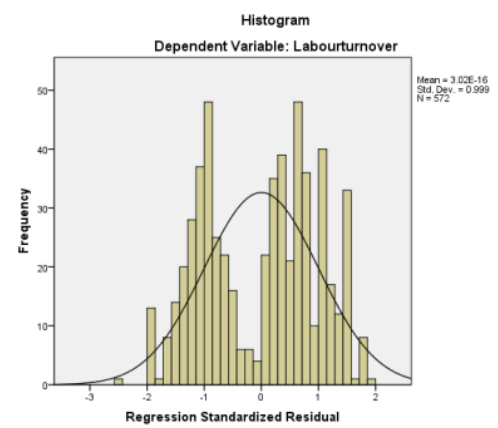

(a)

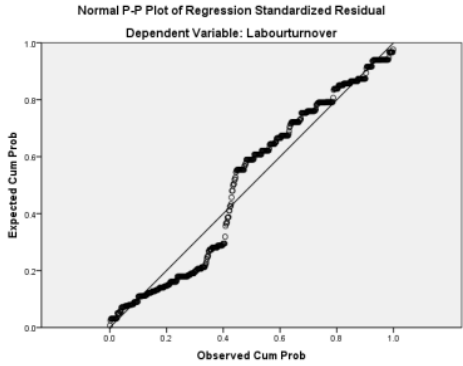

(b)

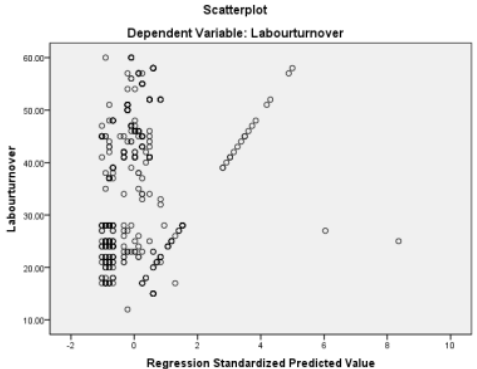

(c)

Fig. 4. Histogram, Normal P-P Plot, and Scatterplot of hypothesis four.

The analysis revealed an $\mathrm{R}$-value of $.175^{\mathrm{a}}$ at a confidence level of 95 per cent $\left(\mathrm{p}=0.000^{\mathrm{a}}<0.05\right)$, with this result the raised hypothesis is rejected, implying a significant contribution of training to labour turnover. Also, the $\mathrm{R}^{2}-\mathrm{value}$ of 0.031 implies that $31 \%$ variance of labour turnover is accounted for by training. Also, the ANOVA showed a significant joint linear association of training to labour given by the $\mathrm{F}(1,571)=18.032 ; \mathrm{p}<0.05$. The adjusted $\mathrm{R}^{2}$ (0.029) confirms some reduction of the unadjusted value (0.031) indicating that the model could be generalised on the population. With this result, it was decided that training bonuses significantly contribute to labour turnover in the telecommunications industry in South-South, Nigeria.

\section{Conclusion and Recommendations}

Labour turnover is a serious challenge in the telecommunications industry and is one of the major difficulties facing human resource managers in the telecommunications sector. Telecommunications industry through the services they provide carryout with vital role they perform in the economy. The continuous growth of the Nigerian telecommunications industry is said to have a direct and indirect benefit to the growth of the Nigerian economy. The findings of this study revealed that labour turnover in the telecommunications industry in South-South Nigeria, are high, and are affected by different aspects of employee inducements. High labour turnover in the telecommunications industry influences both employees and employers. The study further demonstrated that improving employee inducements, in terms of staff promotion, performance-based bonuses, employee discounts, and training is crucial for reducing turnover among the telecommunications workers in South-South, Nigeria. Based on the findings, the study recommends thus,

a) The internal feedback channels of Telecommunications Company should be strengthened in a way that will make employees think positively about their organization.

b) Management of telecommunication companies should make it their priority to conduct frequent employee satisfaction survey to be able to know the actual needs of their workers.

c) Telecommunication companies should annually compare and align their salary structure with that of other organization.

d) The retirement benefits of middle-aged employees should be made very completive to dissuade them from leaving the organization because losing those means losing their most skilled and experienced hand.

\section{References}

Aamodt, M. G. (2007). Industrial/organizational psychology: An applied approach. Belmont, CA: Thomson Higher Education.

Abassi, S. M. \& Hollman, K. W. (2000). Turnover: The real bottom line. Public Personnel Management, 2(3), 333342 
Adah, J. A., Angioha, P. U., Ugwuonwu, C. V., \&Akomaye, S. (2020), "An Empirical Analysis of the Relationship between Working Condition and the Effectiveness of Employees in Commercial Banks in Cross River State" Journal of Banking and Finance Management, 3(2), 2020, pp. 18-24.

Agba, A. M. O. \& Ushie, E. M. (2013). Wage differentials and industrial disputes in Nigerian hospitals. Journal of Business and Management, 11(5), 1-12.

Agba, A. M. O., Mboto, W. A. \& Agba, M. S. (2013). Wages or other conditions: A critical assessment of factors in workers' performance in Nigeria. International Journal of Academic Research in Business and Social Sciences, 3(7), 489-505.

Agba, A. M. O., Nkpoyen, F. \& Ushie, E. M. (2010). Career development and employee commitment in industrial organizations in Calabar, Nigeria. American Journal of Scientific and Industrial Research, 1(2), 105-114.

Agba, A. M., Ushie, M. E., Abam, F. I., Agba, M. S. \& Okoro, J. (2010). Developing the biofuel industry for effective rural transformation. European Journal of Scientific Research, 40(3), 441-449.

Angioha, P. U., Nwagboso, S. N., Ironbar, A. E. \& Ishie, E. U. (2018). Underemployment: A sociological and policy analysis of workers well-being in hospitality industry in Calabar, Cross River State, Nigeria. Journal of Humanities and Social Science (IOSR-JHSS), 23(6), 57-66.

Angioha, P. U., Omang, T. A., Ishie, E. U., \& Iji, M. E. (2020)., "Employee Stressors and Wellbeing of Healthcare Workers in Government owned Hospitals in Calabar, Nigeria", Journal of Public Administration, 2(4), 2020, pp. 36-43

Asmamaw, A. (2011). Professional employees turnover and retention practices of Ethiopian Public Sector Organizations of Ministry of Finance and Economic Development (Mofed). Doctoral Dissertation, Addis Ababa University

Attah, F. M. \& Angioha, P. U. (2019). Examining the level of relationship between working condition predictor variables: Remuneration, working hours, office design, job security and workers wellbeing and productivity in commercial banks. International Journal of Scientific and Research Publications (IJSRP), 9(5), DOI: http://dx.doi.org/10.29322/IJSRP.9.05.2019.p896.

Carson, P. P., Carson, K. P. Griffeth, R. W. \& Steel, R. W. (1994). Promotion and employee turnover: Critique, metaanalysis, and implications. Journal of Business and Psychology. 8(4), 455-466.

Chen, M. (2014). The effect of training on employee retention. In T. Chou (Ed.) 2014 International Conference on Global Economy, Commerce and Service Science (GECSS-14). Phuket: Atlantis Press.

Fernando, A. G. N. K. \& Ranaweera, R. A. A. K. (2019). Study on the impact of non-financial rewards on turnover intention: Mediating role of intrinsic motivation (with special reference to the Hotel Industry of Sri Lanka). International Journal of Scientific and Research Publications, 9(8), 239-244

Govindarajulu N, Bonnie, F. Daily. (2004). Motivating employees for environmental improvement. Industrial Management and Data Systems, 104(4), 364-372.

Hartman, R. J., Kurtz, E. M. \& Moses, E. K. (1994). Synthesis of transit practice 3: Incentive programs to improve transit employee employee's productivity. New York: National Academy Press

Hassan, W., Razi, A., Qamar, R., Jaffer, R., Suhail, S. (2013). The effect of training on employee retention. Global Journal of Management and Business Research Administration and Management, 13(6), 16-20

Iji, M. E, Angioha P. U. \& Okpa, J. T. (2019). Working Hours and Job Security: An Analysis of Their Relationship with Commercial Bank Workers Well-Being and Performance in Cross River State, Nigeria. European Journal of Economic and Financial Research, 3(4).

Iji, M. E., Ojong, F. \& Angioha, P. U. (2018). Microfinance Credit Programmes: Implications on Poverty Reduction in Southern Senatorial District of Cross River State, Nigeria. Journal of Humanities and Social Science, 23(6), 38-45. 
Jang, M., Kim, J. \& Yoo, B. (2017). The impact of e-training on HR retention in midsized firm. Academy of Entrepreneurship Journal, 23(2), 1-11

Mendis, M. V. S. (2017). The impact of reward system on employee turnover intention: A study on Logistics Industry of Sri Lanka. International Journal of Scientific \& Technology Research, 6 (9), 67-72.

Sitati, N., Were, S. \& Waititu, G. A. (2016). Effects of job promotion on employee retention in hotels in Kenya. The Strategic Journal of Business and Change Management, 3(4). 